PRACTICAL PROFESSIONAL GASTRONOMY 


\section{PRACTICAL PROFESSIONAL GASTRONOMY}

H. L. Cracknell, F.H.C.I.M.A., A.C.F. and

G. Nobis, B.A.(Hons), M.H.C.I.M.A.

Introduction by Michael Maclagan, Trinity College, Oxford

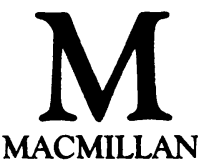




\section{H. L. Cracknell and G. Nobis 1985}

All rights reserved. No reproduction, copy or transmission of this publication may be made without written permission.

No paragraph of this publication may be reproduced, copied or transmitted save with written permission or in accordance with the provisions of the Copyright Act 1956 (as amended).

Any person who does any unauthorised act in relation to this publication may be liable to criminal prosecution and civil claims for damages.

First published 1985

Published by

MACMILLAN EDUCATION LTD

Houndmills, Basingstoke, Hampshire RG21 2XS

and London

Companies and representatives

throughout the world

British Library Cataloguing in Publication Data

Practical professional gastronomy

1. Food 2. Caterers and catering

I. Title II. Nobis, G.

$641.3^{\prime} 0024642$ TX353

ISBN 978-0-333-36104-7

DOI 10.1007/978-1-349-17876-6

ISBN 978-1-349-17876-6 (eBook)

ISBN 978-0-333-36104-0 Pbk 


\section{Contents}

List of Illustrations ix

Preface xi

Acknowledgements xii

Introduction xiii

1 A STUDY OF FOOD AND THE DEVELOPMENT OF EATING HABITS 1 The Evolution of Practices - Fulfilment of Requirements - Man's Food Materials - People and Environment - Food Supply and Man's Eating Habits - The Genesis of Eating Habits - Effects of Taboos and Religion Religious Acceptances and Restrictions of Alcohol Consumption

\section{MAN'S SENSES}

The Dietary Connection - The Senses and Gastronomy - The Visual Sense in Gastronomy - The Auditory Sense - The Taste of Food - Taste Perception in Man - The Sense of Smell - The Sense of Touch - Temperature and Taste - Sensitivity to Pain - Organoleptic Aspects of Quality Recognition - Habituation of the Senses - Meals and Habituation - Methods for Avoiding Habituation of the Senses - Wisdom and Fallacy of Food Choice - The Sequence and Content of Courses - The Flavouring of Foods

\section{NUTRIMENTAL ASPECTS}

Eating as a Necessity - Man's Nutritional Requirements - Innate Food Characteristics - Dietary Requirements - Digestion - Considerations of Digestion - Environmental Effects - Cultural Limitations - Societal Influences - The Meal and the Occasion - Good Food and Bad Food Alcohol

\section{THE PROGRESSION OF GASTRONOMY}

Food Habits of Ancient Greece - Eating in Ancient Rome - The Egyptian Contribution - Eating in Great Britain in Early Times - Elizabethan Meals

- The French Approach and Contribution - Cooking Methods through the Ages - The British at Dinner - The Pattern of Living of the Wealthy The London Season - Domestic Staff - The Influence of Cookery Books The Great Chefs - The Influence of Food Guides - Restaurant Gradings Culinary Associations - Gourmet Societies - Food Writers - Museums 
The Purpose of the Menu - Need for Originality - Menu Layout - The History of Menus - Means of Communication - Meals of the Day - Classes of Establishment and Staff - Qualities of Waiting Staff - Briefing of Waiting Staff - Correct Dress for the Customer - Food Preferences Prices on Menus - Menu Publicity - Merchandising the Meal - Food Standards - Food Additives - Menu Truquage - The Role of Standardised Recipes

6 MENU PLANNING

General Principles - The Profile of the Customer - The Meal and the Occasion - The Range of Menus - The Sequence of Courses - The Selection of Dishes - The Availability of Supplies - Capabilities of Staff - Equipment and Utensils - The Nutritional Aspects - The Language of the Menu Food Combinations - Pricing the Menu

\section{MENU AND WINE LIST COMPOSITION}

Who Writes the Menu? - Suitability of Foods - Special Function Menus Classical Menu Terminology - Other Entries on Special Function Menus Composing the Wine List - Cyclical Menus - Calendar of Seasons - Menu and Wine List Production - Printing the Menu and Wine List - The Phraseology of Menus and Wine Lists

8 A HISTORY OF THE ART OF THE TABLE AND SERVICE

Introduction - China - The Middle East - Greece - Rome - Ancient Gaul Italy - France - Great Britain - Recent Developments - La Nouvelle Cuisine Française

\section{THE ROLE OF ALCOHOLIC BEVERAGES}

The Names on the Wine Label - France - Germany - Italy - Spain Portugal - Madeira - Australia - Austria - Bulgaria - Cyprus - Greece Hungary - Israel - Romania - Russia - South Africa - Switzerland United States - Yugoslavia - British Wines - Cocktails -Spirits and Liqueurs - Aromatic Bitters - Cure for a Hangover - Vintage Guides Wines and Foods - How to Hold a Wine Tasting - Smoking 
Benelux - Bulgaria - China - Czechoslovakia - Denmark - Finland France - Germany - Great Britain - Greece - Holland - Hungary India - Israel - Italy - Japan - Mexico - The Middle East Countries Poland - Portugal - Romania - Russia - Spain - Sweden and Norway Switzerland - United States - West Indies - Yugoslavia - Soul Food Rastafarians - Vegetarian Meals

\section{THE CREATION OF A GASTRONOMIC OCCASION}

The Requirements - Preparing for the Occasion - Some Aphorisms on Dining - The Theme - The Menu Content and the Menu Card - Matching the Menu to the Occasion and the Person - Historical Occasions - Burns' Night Bill of Fare - Stage Management of the Occasion - Spectacular Occasions - Spectacular Occasions - Medieval Banquets - The Role of the Toastmaster - Gastronomic Occasions - Unconventional Meals - Guidance for Gastronomic Themes - The Environment and Function Management Service - Superstition - Etiquette - Table Manners

\section{GASTRONOMY AND GASTRONOMES}

What is Gastronomy? - What is a Gastronome? - Pierre Androuet - Paul Bocuse - Marcel Boulestin - J. A. Brillat-Savarin - Antonin Carême Robert Courtine - Fanny Cradock - Curnonsky - Elizabeth David Escoffier - Mario Gallati - Michel Guérard - Philip Harben - Ambrose Heath - E. Herbodeau - Roger Lallemand - Rosa Lewis - E. Longue Lucien Ogier - R. Oliver - Marguerite Patten - H. P. Pelleprat - Pomiane Raymond Postgate - Mme Prunier - C. Ritz - Albert and Michel Roux André Simon - Soyer - Toulemon - Jean and Pierre Troisgros - Vatel Roger Vergé and Others

\section{PLACES OF ENTERTAINMENT}

An Outline of the Functions of Establishments - Profit Sector Eating and Entertaining Places - The Sun Inn - Mine Host - Restaurants - Coffee Shops - Cafes - Coffee Bars - Clubs - Bistros - Estaminets - Brasseries Grill Rooms - Chop Houses - Trattorie - Tavernas - Osterie - Pizzerie Butteries - Public Houses - Night Clubs - Fast Food Outlets - Takeaways Holiday Camps - Catering for Leisure - Ships' Catering - Railway Catering - Coach Catering - Motorway Catering - Airway and Airport Catering - Departmental Stores Catering - Fish and Chip Shops and Restaurants - Outdoor Catering - Cost Sector Eating Places - Catering in Hospitals - Industrial Catering - Catering on Oil Rigs and in Camps Educational Establishment Catering - Catering in Colleges - University Catering - Catering for the Social Services - Catering in HM Forces NAAFI 
Appendixes

A. The Naming of Dishes - Naming Dishes after People - Naming Dishes after Places and Events - Calendar of Main Anniversaries

B. Culinary Sayings, Proverbs and Poems

C. Education for Gastronomy

392

D. The Menu as an Art Form

395

E. The Physiology of Taste

Select Bibliography

Index

406 


\section{List of Illustrations}

1. A banqueting scene from a fresco in an Etruscan royal tomb, dating from the sixth century $\mathrm{BC}$

2. Fish formed an important part of the Roman diet; the Mediterranean provided a rich harvest, as this first century mosaic from Pompeii shows

3. A sixteenth-century kitchen (from Bartolomeo Scappi's Opera of 1570) 53

4. Mestole, schiumarole and other utensils (from Bartolomeo Scappi's Opera of 1570)

5. Mrs Beeton: a photo used in Nancy Spain's Life of her grandmother

6. The kitchens at Christ Church Oxford in the eighteenth century

7. The kitchens at the Royal Pavilion, Brighton, in their heyday

8. A supper menu from the Savoy, 1903 (printed on silk)

9. Menu for 'Her Majesty's Déjeuner', October 1844

10. Menu for a banquet at Fishmongers' Hall, 1863

11. Menu for The Royal Wedding Breakfast, July 1885

12. Menu for an official banquet at Aldershot, 1871

13. On any menu the wines and dishes should be chosen to complement one another

14. A menu from the Worshipful Company of Cooks

15. What the customer reads on the menu should improve his appetite

16. 'The Cooks Rout or High Life below stairs'. An eighteenth-century engraving

17. John Farley, principal cook at the London Tavern

18. Grands Vins des Hospices de Beaune

19. A nineteenth-century certificate of admission to the freedom of the Worshipful Company of Cooks

20. The Banqueting Room at the Royal Pavilion, Brighton 
21. Preparation for a banquet at the Guildhall, London, at the beginning of this century

22. The menu served on the occasion of the cutting of the first sod of what was to become the Great Central Railway's ill-fated main line to London 291

23. Charles Elmé Francatelli

24. Brillat-Savarin

25. Antonin Carême

26. Miss Rosa Lewis and her staff, at the Cavendish Hotel, Jermyn Street, W1, in May 1938

27. Alexis Benoit Soyer, from the original by Emma Soyer 338

28. The Holborn Restaurant, part of the Frederick Gordon empire 344

29. An early nineteenth-century Parisian restaurant bill 350

30. A pioneer of fast food - 'Le Marchand de Macaroni à Naples' 358

31. William Towle, General Manager of the London Midland and Scottish Railway Company at the Adelphi Hotel, Liverpool, 1912 


\section{Preface}

The subject of gastronomy as a body of knowledge is one that gives rise to much controversy, the main difficulty being to confine its scope within clearly defined parameters of conventional disciplines as associated with culinary practices.

This book is written to give guidance to those engaged in the provision of food and drink so that they may improve their knowledge, extend the frontiers of the art and science of gastronomy, and achieve yet higher standards.

The approach is interdisciplinary and an attempt is made to transcend the conventional boundaries of present practice. The axis is the interconnection between man, his food and drink, the environment and the development of cookery practices. All these factors have to be considered in the light of the prevailing cultures of mankind and be based on the accumulation of nutritional knowledge that shapes our eating habits.

It is hoped that the contents of this book will stimulate a desire to learn more about the eating habits of nations and why means of nourishment are often imposed by geographical chance. Such studies can be a means of gaining a closer understanding of our fellow men and strengthen the brotherhood of man. A knowledge of man's physiological needs and of his psychological characteristics is considered necessary in order to understand the way in which present-day eating practices including table manners and other forms of etiquette, have come about by a prolonged process of progression of all the many strands that go to form the subject of oenogastronomy.

On a more practical plane, it is suggested that a basic knowledge of the principles of menu composition is essential because it is fundamental to every gourmet occasion. It is essential that the menu and wine list is absolutely right before any of the other aspects of gastronomy are planned.

The authors believe that the pleasures that can be obtained from a knowledge and love of good food and drink are not the sole prerogative of the wealthy. The knowledge of good food and drink can be applied right across the wide expanse of catering activities and at all levels as a means of making man's journey through life more pleasurable.

H. L. C.

G. N. 


\title{
Acknowledgements
}

The authors and publishers wish to thank the following for permission to reproduce illustrations:

\author{
BBC Hulton Picture Library \\ Bodleian Library, Oxford \\ Borough of Brighton Royal Pavilion, Art Gallery and Museums \\ Christmas Archives and Photo Library \\ Guildhall Library, London \\ Mansell Collection \\ Museo Nazionale Napoli \\ National Monuments Record \\ National Railway Museum
}

The publishers have made every effort to trace the copyright holders, but if any have been overlooked, the necessary arrangements will be made at the first opportunity. 


\section{Introduction}

I first met Mr Harry Cracknell, one of the joint authors of this book, in 1972. The occasion was an interesting one, for with a colleague he had organised a gastronomic dinner in the Department of Catering Management at the Oxford Polytechnic. Thus was founded a Society 'devoted to furthering the Appreciation of Good Food and Wine', which at its second meeting adopted the name of Brillat-Savarin. The preparation of the carefully selected menus gave a rare opportunity to the students to produce dishes of the highest expertise; furthermore, each feast was followed by an opportunity for the diners to express their opinions on what they had been eating.

In this volume the authors have a comparable dual approach. The consumption of food and wine is very properly seen as an art, but it is viewed from the point of view of the cook and the restaurateur as well as from that of the diner. Certain primitive tribes, we are assured by anthropologists, regard the act of eating as indecent and only to be performed in private while other functions may freely be exercised in public view. I do not share their views, nor do the authors of this highly informative book. On the contrary they share the view of Anthelme de Brillat-Savarin, which adorned the menu of which I wrote above:

The pleasures of the table belong to all times and all ages, to every country and every day; they go hand in hand with all our other pleasures, outlast them, and remain to console us for their loss.

I count myself fortunate to have been brought up in a family where both food and wine were taken seriously, and then to have lived much of my life in Oxford where the same conditions have prevailed. As one looks back over the years of consumption, it is simple to see how personal tastes are conditioned by events outside one's control. Even today I am not over-fond of brains, and I think this goes back to the end of the First World War when they were (I believe) not rationed and thought to be wholesome for children. On the other hand, I like my game well-hung: this may go back to my mother's father, whose prescription was simple, if perchance extravagant: 'Hang two pheasants up by the beak: when one falls off, eat the other.' Two very large changes have occurred in the provision of food within my memory. One is the revolution of transport, which has brought exotica from every land to our tables; the other is the considerable replacement of small suppliers by multiple concerns with a consequent elimina- 
tion of the unusual or the specialised. My mother, herself an excellent cook, would feel aggrieved if she could not get that admirable fish, John Dory - the Poisson St Pierre of legend - from our local fishmonger in South Kensington. When on festive occasions she bought from him what nowadays are ubiquitously styled 'scampi' they went under the more appropriate name of Dublin Bay Prawns. And in truth the large prawn of home waters is not the same as its cousin of the Venetian lagoons. Viewing a modern retailer of fish one sometimes feels that one would welcome more products from home waters and fewer 'Pacific prawns'. How gladly would I trade many imported cheeses for a regular supply of Blue Vinney.

The authors of this book have cast their net wide. Food from every area of the world comes under their scrutiny, as does also its preparation from the age of Greece and Rome. But the scientific aspects are by no means neglected. It would seem that we all need a regular intake of five chemical substances in recognisable proportions. I think I was vaguely aware that I required a daily intake of two and a half litres of water, though I am always prepared to compromise by ingesting some of it in the form of wine. After all it is not necessary to drink wine of the highest class all the time. There is a little to be said for the attitude of Mr Mountchesney in Disraeli's Sybil: 'P'rather like bad wine, one gets so bored with good wine.' However, I had no conception that I needed a daily intake of ten to fourteen megajoules of energy every day. Strict vegetarians should perhaps add to their diet vitamin B12, which is only present in animal sources of food.

It is to the credit of the authors that they do not shirk the practical side of constructing a menu. In a fixed-price menu, the main dish should take some 62 to 72 per cent of the total cost. It is an interesting reflection that restaurants as we understand them, that is true eating places as opposed to inns and taverns, only came into existence in the eighteenth century. Even then certain practices which we would expect were slow to become common. According to family tradition, it was only in the 1870s that an English diplomat, Sir William Barrington, persuaded the great establishments of Paris that hot plates contributed to the better enjoyment of great food.

Some of the historic meals which the two authors have discovered make fascinating reading; they range from a dinner at York contrived by the great Alexis Soyer using 180 fowls but only cooking the tiny portion known as the 'sot l'y laisse' (often in English usage 'the oyster') to a French meal organised by President Loubet which entailed the consumption of 50000 bottles of wine and the washing up of a quarter of a million plates!

Mercifully, fashions change from age to age and vary from continent to continent. In the Middle Ages whale was esteemed a delicacy, but it could not recover that qualification in the last war. In New Zealand (I was delighted to discover) the flesh of the sheep is described by its age - hogget, shearing, and so on.

Less attention is paid nowadays to the gastronomic requirements of abstinence on fast days or in Lent. My grandmother, a sister of the diplomat mentioned above, preserved a menu from Paris for Good Friday 1877. 


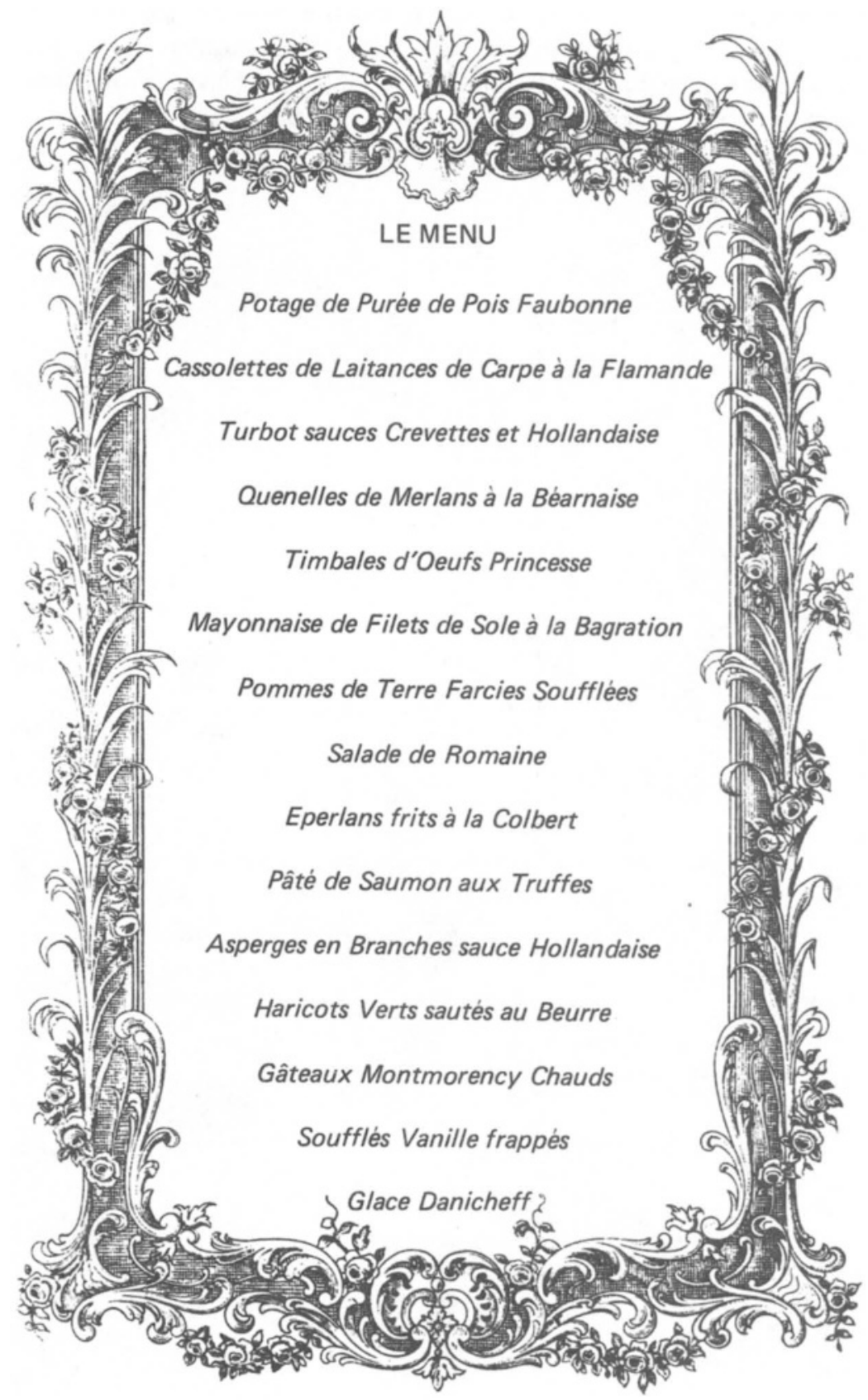


It will be observed that this simple little repast is indeed 'maigre' throughout by the strictest rules.

It is tempting to quote further from the extensive variety of sources employed in this fascinating and truly 'free-range' volume, but the reader must do his own research. For myself I wish the book every success. It balances splendidly the interests of those who consume and those who prepare.

Michael Maclagan 


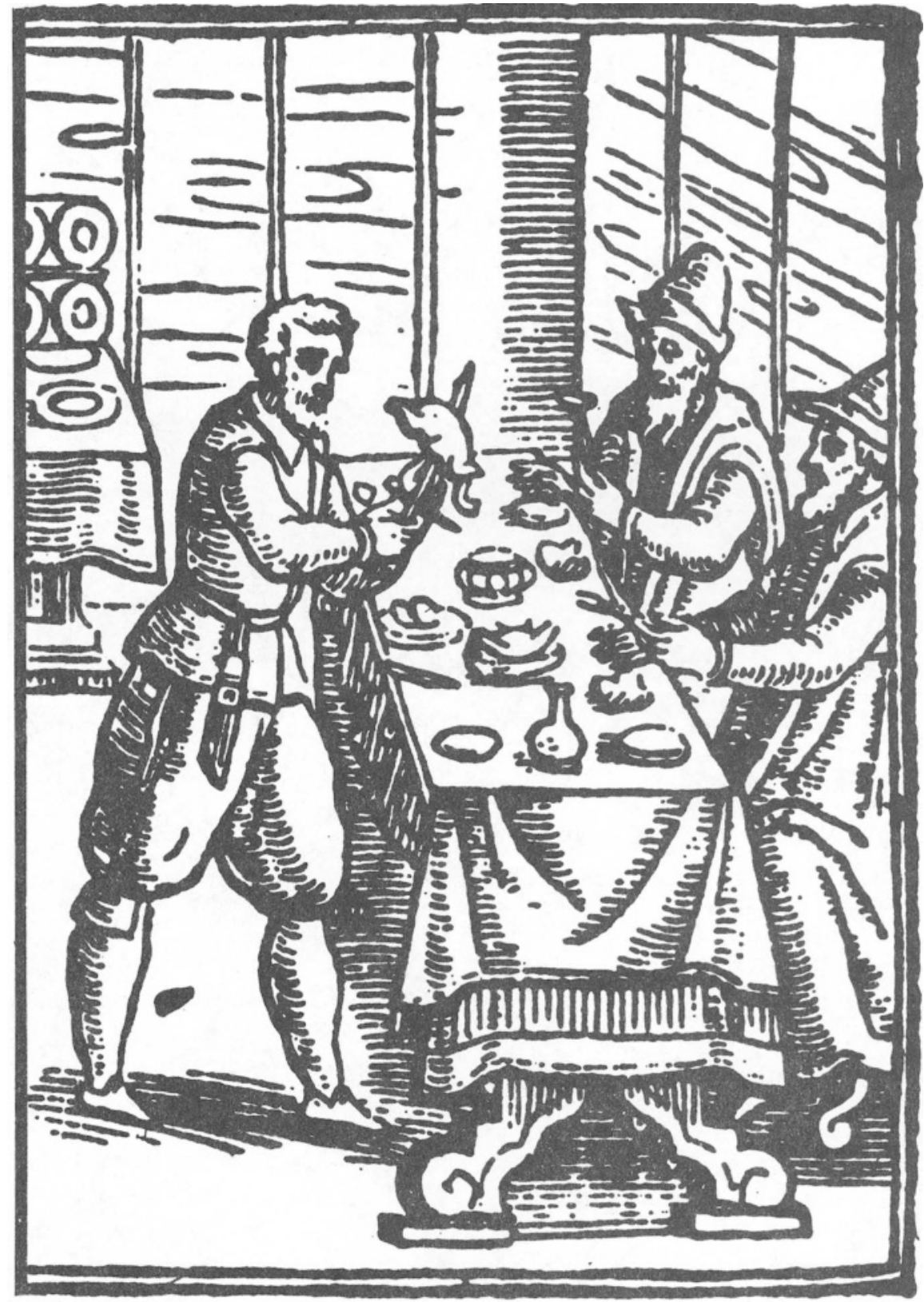

